\title{
Comparative evaluation of analgesic efficacy of tramadol and diclofenac-sodium in post-operative orthopedic patients
}

\author{
Rama Paudel $^{1 *}$, Anjali Deka² ${ }^{2}$ Hemant Kumar Gupta ${ }^{3}$, Hari Prasad Nepal ${ }^{4}$
}

${ }^{1}$ Department of Pharmacology, Universal College of Medical Sciences-Teaching Hospital, Bhairahawa, Nepal

${ }^{2}$ Department of Pharmacology, College of Medical Sciences-

Teaching Hospital, Bharatpur, Nepal

${ }^{3}$ Department of Orthopedics, College of Medical SciencesTeaching Hospital, Bharatpur, Nepal

${ }^{4}$ Department of Microbiology, Trinity School of Medicine, St. Vincent and the Grenadines

Received: 24 August 2017

Accepted: 21 September 2017

*Correspondence to:

Dr. Rama Paudel,

Email: paudelrama2015@ gmail.com

Copyright: (C) the author(s), publisher and licensee Medip Academy. This is an openaccess article distributed under the terms of the Creative Commons Attribution NonCommercial License, which permits unrestricted noncommercial use, distribution, and reproduction in any medium, provided the original work is properly cited.

\begin{abstract}
Background: Post-operative pain management is an important consideration in the orthopedic department. The purpose of this study was to compare the analgesic efficacy of tramadol with diclofenac sodium in patients with postoperative orthopedic pain.

Methods: A hospital based, prospective, observational study was undertaken in Department of Orthopedics for a period of one year. A group of 60 patients having post-operative pain intensity assessed as $6 \mathrm{~cm}$ or more on a $10 \mathrm{~cm}$ visual analogue scale (VAS) were assigned to receive either tramadol thrice a day $(n=30)$ or diclofenac sodium thrice a day $(n=30)$. Both drugs were administered parenterally for initial $24 \mathrm{hr}$, then orally for next $96 \mathrm{hr}$. The primary efficacy outcome measures were pain intensity difference assessed at $2 \mathrm{hr}, 4 \mathrm{hr}, 8 \mathrm{hr}, 16 \mathrm{hr}, 24 \mathrm{hr}, 32 \mathrm{hr}, 40 \mathrm{hr}$, $48 \mathrm{hr}, 56 \mathrm{hr}, 64 \mathrm{hr}, 72 \mathrm{hr}, 80 \mathrm{hr}, 96 \mathrm{hr}, 104 \mathrm{hr}, 112 \mathrm{hr}$ and $120 \mathrm{hr}$ using a VAS and sum of pain intensity differences assessed at $8 \mathrm{hr}, 24 \mathrm{hr}, 48 \mathrm{hr}, 72 \mathrm{hr}, 96 \mathrm{hr}$ and $120 \mathrm{hr}$ whereas secondary efficacy measures included maximum fall in pain intensity, number of patients who required rescue medication and their quality of sleep in the night.
\end{abstract}

Results: Mean pain intensity differences assessed on $10 \mathrm{~cm}$ VAS were significantly better for tramadol group compared to diclofenac group at all the time points except $88 \mathrm{hr}$. Sum of pain intensity differences over $8 \mathrm{hr}, 24 \mathrm{hr}, 48 \mathrm{hr}$, $72 \mathrm{hr}, 96 \mathrm{hr}$ and $120 \mathrm{hr}$ for the tramadol group was significantly superior than diclofenac group. Maximum fall in pain intensity score was also significantly superior in the tramadol group as compared to the diclofenac group. However, no patients required rescue medication in either of the groups. Patient's quality of sleep improved with both drugs but tramadol produced significantly better quality of sleep every night than did diclofenac. Both the study medications produced effective analgesia and were well tolerated with no incidence of serious adverse effects throughout the study.

Conclusions: Tramadol has a more pronounced analgesic effect than diclofenac. Thus, tramadol can be considered as an effective alternative to traditional NSAIDs in the treatment of post-operative pain.

Keywords: Analgesic efficacy, Diclofenac, Post-operative orthopedic pain, Tramadol, VAS

\section{INTRODUCTION}

Pain is the most common clinical complaint and causes considerable human suffering. ${ }^{1}$ Pain control is such an important factor that it has permitted surgery to progress enormously; however, postoperative pain still tends to be underestimated, is generally treated inadequately, and therefore, is not assessed with regard to how it harms the patient and impedes successful recovery. ${ }^{2}$ The clinicians do everything possible to eliminate postoperative pain without causing additional problems, such as respiratory or vascular depression, gastrointestinal and visceral motility disorders, coagulation anomalies, and drug tolerance and dependence. ${ }^{2}$ 
Despite the availability of a wide variety of analgesic drugs, routine management of postoperative pain remains a continuing challenge. ${ }^{3}$ Approaches to pain relief may differ depending on the type of surgery, the patient, and the drugs administered. ${ }^{2}$ The best postoperative pain regimen is one that offers broad analgesic coverage, is easy to administer, and is safe. ${ }^{2}$

In the past, narcotics were used as strong analgesics as they were used in relieving severe acute or chronic pain. ${ }^{4}$ However, high dose of narcotics leads to side effects such as respiratory depression, apnoea, nausea, vomiting, itching and physical and mental dependence. ${ }^{4}$ Moreover, the use of high dose of bolus or continuous infusion of some narcotics, such as alfentanil, increase pain because of the fast absorption and tolerance. ${ }^{4}$

Non-steroidal anti-inflammatory drugs (NSAIDs) are commonly used for post-operative pain treatment. ${ }^{5}$ Among NSAIDs, diclofenac-sodium is widely used as a most efficacious agent. ${ }^{6}$ It has an analgesic, antipyretic and antiinflammatory effects. ${ }^{7}$ Therefore, it could have an influence on fracture healing. The action of this drug is based on the inhibition of cyclo-oxygenase (COX) which converts the arachidonic acid that is set free from the cell wall into prostaglandin, prostacycline and thromboxane. ${ }^{7}$ However, NSAIDs have been reported to be associated with various complications such as upper gastrointestinal complication, platelet function inhibition, increase in perioperative bleeding and nephrotoxicity in patients with and without pre-existing renal insufficiency. ${ }^{5,8}$

The search for appropriate drugs to treat patients with moderate-to-severe pain has led to the development of tramadol hydrochloride. ${ }^{2}$ It is a synthetic drug that offers interesting characteristics. ${ }^{9}$ The drug is a centrally acting aminocyclohexanol analgesic with complementary mechanisms including activation of $\mu$ - opioid receptors and inhibition of norepinephrine and serotonin reuptake. ${ }^{10}$ There is less evidence of drug dependence, respiratory depression and gastrointestinal disorders. ${ }^{11}$

Though numerous studies have compared tramadol and diclofenac in post-operative pain treatment in various types of surgical procedures, comparative studies on their efficacy in post-operative orthopedic patients are very limited. ${ }^{12-15}$ Therefore, we aimed to conduct this study in post-operative orthopedic patients at College of Medical Sciences-Teaching Hospital (CMS-TH), Chitwan, Nepal.

\section{METHODS}

The study was a hospital based, prospective, observational study conducted during the period of one year (July 2012June 2013) in the Department of Orthopedics at College of Medical Sciences-Teaching Hospital (CMS-TH), a tertiary care center located at Bharatpur, Chitwan, Nepal. Sixty patients who had undergone orthopedic surgery and fulfilled the inclusion criteria were included in the study (Table 1).
Table 1: Inclusion and exclusion criteria.

\begin{tabular}{|c|c|}
\hline Inclusion criteria & Exclusion criteria \\
\hline $\begin{array}{l}\text { Patients willing to } \\
\text { participate in the study }\end{array}$ & $\begin{array}{l}\text { Patients allergic to } \\
\text { NSAIDs or opioids }\end{array}$ \\
\hline $\begin{array}{l}\text { Patients of both genders } \\
\text { above } 18 \text { years }\end{array}$ & Pregnant women \\
\hline $\begin{array}{l}\text { Patients who have } \\
\text { undergone orthopedic } \\
\text { surgery }\end{array}$ & $\begin{array}{l}\text { Patients with known } \\
\text { alcohol or drug addiction } \\
\text { or abuse }\end{array}$ \\
\hline $\begin{array}{l}\text { Patients weighing } 50 \text { to } \\
80 \mathrm{~kg}\end{array}$ & $\begin{array}{l}\text { Patients receiving any } \\
\text { other NSAIDs (except for } \\
\text { the study medication) }\end{array}$ \\
\hline \multirow[t]{5}{*}{$\begin{array}{l}\text { Patients with pain } \\
\text { intensity at rest of at least } \\
6 \mathrm{~cm} \text { on a horizontal } 10 \\
\mathrm{~cm} \text { visual analogue scale } \\
\text { (VAS) }\end{array}$} & $\begin{array}{l}\text { Patients receiving CNS } \\
\text { depressants or warfarin }\end{array}$ \\
\hline & $\begin{array}{l}\text { Patients with increased } \\
\text { intra cranial pressure or } \\
\text { head injury }\end{array}$ \\
\hline & $\begin{array}{l}\text { Patients weighing less } \\
\text { than } 50 \mathrm{~kg} \text { or more than } \\
80 \mathrm{~kg}\end{array}$ \\
\hline & $\begin{array}{l}\text { Patients with history or } \\
\text { suspicion of gastro } \\
\text { duodenal ulcer and gastro } \\
\text { intestinal (GI) bleeding }\end{array}$ \\
\hline & $\begin{array}{l}\text { Patients with cardiac, } \\
\text { hepatic or renal } \\
\text { insufficiency }\end{array}$ \\
\hline
\end{tabular}

A total of 30 eligible patients were selected in each of two groups. Each of the patients received either diclofenacsodium or tramadol as an analgesic therapy. Both the drugs were administered parenterally for initial $24 \mathrm{hr}$ then, orally for next 4 days (Table 2).

Table 2: Dose and duration of study medication.

\begin{tabular}{|ll|}
\hline Drug & Dose and duration \\
\hline Diclofenac-sodium & $\begin{array}{l}75 \mathrm{mg} \text { IM thrice a day for 24hr } \\
\text { followed by 50mg oral thrice a } \\
\text { day for next 4 days }\end{array}$ \\
\hline Tramadol & $\begin{array}{l}\text { 100mg IM thrice a day for 24hr } \\
\text { followed by 50mg oral thrice a } \\
\text { day for next 4 days }\end{array}$ \\
\hline
\end{tabular}

\section{Pain assessment}

Pain was assessed at different time points $(2 \mathrm{hr}, 4 \mathrm{hr}, 8 \mathrm{hr}$, $16 \mathrm{hr}, 24 \mathrm{hr}, 32 \mathrm{hr}, 40 \mathrm{hr}, 48 \mathrm{hr}, 56 \mathrm{hr}, 64 \mathrm{hr}, 72 \mathrm{hr}, 80 \mathrm{hr}, 96 \mathrm{hr}$, $104 \mathrm{hr}, 112 \mathrm{hr}$ and $120 \mathrm{hr}$ ) using a VAS, a $10 \mathrm{~cm}$ line with the maximum pain indicated at the right hand side, and no pain at the left hand side (0-no pain, 2-mild pain, 4tolerable pain, 6-distressfull pain, 8-severe pain, 10-totally disabling pain) (Figure 1). ${ }^{16,17}$ 


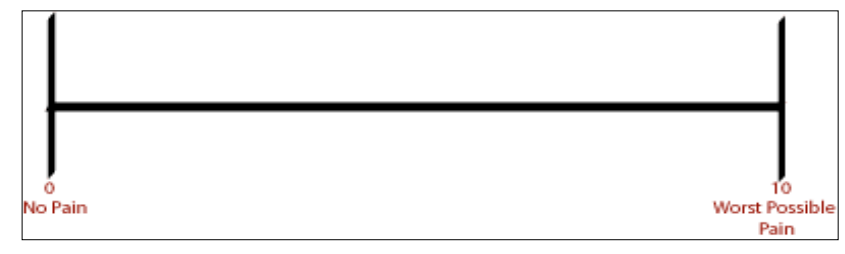

Figure 1: 10cm Visual Analogue Scale (VAS)

The pain level was also assessed from the quality of sleep every night using 5 point scale (0-no sleep, 1 -frequent waking, 2-shallow sleep every night, 3-good sleep, 4-deep sleep) as was done by Pagliara et al. ${ }^{9}$

\section{Efficacy criteria}

The primary efficacy outcome measures were pain intensity difference (PID) assessed at different time intervals $(0-2 \mathrm{hr}, 0-4 \mathrm{hr}, 0-8 \mathrm{hr}, 0-16 \mathrm{hr}, 0-24 \mathrm{hr}, 0-32 \mathrm{hr}, 0-$ $40 \mathrm{hr}, 0-48 \mathrm{hr}, 0-56 \mathrm{hr}, 0-64 \mathrm{hr}, 0-72 \mathrm{hr}, 0-80 \mathrm{hr}, 0-88 \mathrm{hr}, 0-$ 96hr, $0-104 \mathrm{hr}, 0-112 \mathrm{hr}$ and $0-120 \mathrm{hr}$ ) and sum of pain intensity differences (SPID) for the first $8 \mathrm{hr}, 24 \mathrm{hr}, 48 \mathrm{hr}$, $72 \mathrm{hr}, 96 \mathrm{hr}$ and 120hr) whereas secondary efficacy measures included maximum fall in pain intensity in each group, number of patients who required rescue medication and their quality of sleep in the night. , $^{3,9,18}$

\section{Rescue analgesia}

If the patient complained of severe pain $(>8 \mathrm{~cm}$ on $\mathrm{VAS})$, acetamenophen upto $650 \mathrm{mg}$ thrice a day was considered to administer to the patients needing rescue analgesia as was used by Beaulieu et al. ${ }^{3,19}$

\section{Adverse events}

Any adverse effects of the drugs were noted.

\section{Statistical analysis}

Data were recorded on predesigned proforma, entered in a Microsoft Office Excel Worksheet. Statistical analysis was done using Statistical Package for Social Sciences (SPSS) software version 16.0. Data were expressed in mean, standard deviation (SD) and percentage. Student's t test and chi-square test were performed to determine the significance. $\mathrm{P}$ value $<0.05$ was considered to be statistically significant.

All the patients were informed before surgery about the study and written informed consent was taken from them prior to the study commencement.

\section{RESULTS}

\section{Demographic features of the study population}

Among a total of 60 post-operative orthopedic patients in our study, the following demographic features were observed:

\section{Gender wise distribution}

In the present study, 33 patients $(55 \%)$ were males and 27 $(45 \%)$ were females. The gender wise distribution of patients in Tramadol and Diclofenac groups was uniform $(\mathrm{P}>0.05)$ (Figure 2).

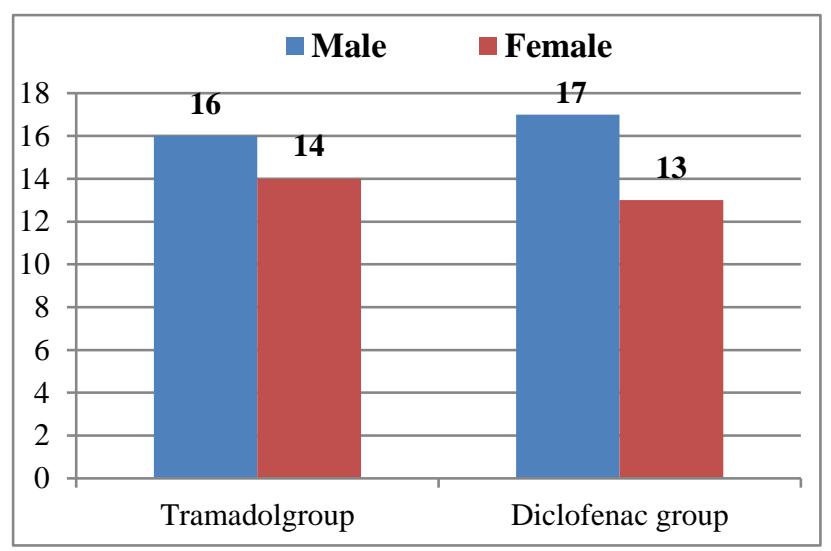

Figure 2: Gender wise distribution of patients.

Mean age of the patients in two groups

The patients in this study ranged from 19 to 65 years. Mean age of the patients in both the treatment groups is shown in Table 3.

Table 3: Mean age of the patients.

\begin{tabular}{|llll|}
\hline Variable & $\begin{array}{l}\text { Tramadol } \\
\text { Group } \\
(\mathbf{n = 3 0})\end{array}$ & $\begin{array}{l}\text { Diclofenac } \\
\text { Group } \\
(\mathbf{n = 3 0})\end{array}$ & P value \\
\hline Age (year) & $34.70 \pm 13.38$ & $32.83 \pm 11.70$ & $0.568^{*}$ \\
\hline *Not significant & & \\
\hline
\end{tabular}

Mean weight of the patients in two groups

Weight of the patients ranged from $51-76 \mathrm{~kg}$. The mean age for each group is presented in Table 4.

Table 4: Mean weight of the patients.

\begin{tabular}{|llll|}
\hline Variable & $\begin{array}{l}\text { Tramadol } \\
\text { Group } \\
(\mathbf{n = 3 0})\end{array}$ & $\begin{array}{l}\text { Diclofenac } \\
\text { Group } \\
(\mathbf{n = 3 0})\end{array}$ & P value \\
\hline $\begin{array}{l}\text { Weight } \\
(\mathrm{kg})\end{array}$ & $61.33 \pm 7.71$ & $61.16 \pm 7.53$ & $0.933^{*}$ \\
\hline *Not significant & & \\
\hline
\end{tabular}

\section{Clinical diagnosis of the patients}

The clinical diagnosis of the patients in each of two treatment groups is depicted in Table 5.

Majority of the patients had femur fracture (18.3\%) followed by humerus fracture $(15 \%)$. 
Table 5: Clinical diagnosis of the patients.

\begin{tabular}{|llll|}
\hline Diagnosis & Tramadol Group $(\mathbf{n}=\mathbf{3 0})$ & Diclofenac Group $(\mathbf{n}=\mathbf{3 0})$ & Total $(\mathbf{n = 6 0})$ \\
\hline Acetabulum fracture & 1 & 0 & $1(1.7 \%)$ \\
\hline Bilateral nasal bone fracture & 0 & 1 & $1(1.7 \%)$ \\
\hline Calcaneus fracture & 1 & 2 & $3(5.0 \%)$ \\
\hline Femur and ulna fracture & 0 & 1 & $1(1.7 \%)$ \\
\hline Femur fracture & 8 & 3 & $11(18.3 \%)$ \\
\hline Humerus fracture & 7 & 2 & $9(15 \%)$ \\
\hline Malleolus fracture & 2 & 2 & $4(6.6 \%)$ \\
\hline Metatarsal fracture & 0 & 1 & $1(1.7 \%)$ \\
\hline Navicular bone fracture & 0 & 1 & $1(1.7 \%)$ \\
\hline Patella fracture & 2 & 2 & $4(6.6 \%)$ \\
\hline Phalanges fracture & 1 & 1 & $2(3.3 \%)$ \\
\hline Pubic fracture & 0 & 2 & $2(3.3 \%)$ \\
\hline Radius and ulna fracture & 0 & 2 & $2(3.3 \%)$ \\
\hline Radius and patella fracture & 1 & 0 & $1(1.7 \%)$ \\
\hline Radius fracture & 2 & 5 & $7(11.7)$ \\
\hline Talus fracture & 1 & 0 & $1(1.7 \%)$ \\
\hline Tibia and fibula fracture & 1 & 3 & $4(6.6 \%)$ \\
\hline Tibia fracture & 3 & 2 & $5(8.4 \%)$ \\
\hline
\end{tabular}

Table 6: Comparison of mean VAS score between tramadol and diclofenac groups at different time points.

\begin{tabular}{|llllllll|}
\hline No. & Time (hour) & \multicolumn{2}{l}{$\begin{array}{l}\text { Mean VAS score } \\
\text { Tramadol group } \\
(\mathbf{n = 3 0})\end{array}$} & $\begin{array}{l}\text { Diclofenac group } \\
(\mathbf{n = 3 0})\end{array}$ & $\begin{array}{l}\text { Mean } \\
\text { difference }\end{array}$ & P value & \multicolumn{2}{c|}{ 95\% Confidence interval } \\
\hline 1. & 0 (Baseline) & $6.90 \pm 0.49$ & $6.70 \pm 0.53$ & 0.20 & $0.131^{*}$ & -0.06 & UL \\
\hline 2. & 2 & $5.09 \pm 0.68$ & $5.59 \pm 0.73$ & -0.49 & $0.009^{* *}$ & -0.86 & -1.2 \\
\hline 3. & 4 & $4.43 \pm 0.52$ & $5.00 \pm 0.68$ & -0.57 & $0.001^{* *}$ & -0.88 & -0.25 \\
\hline 4. & 8 & $4.09 \pm 0.42$ & $4.36 \pm 0.51$ & -0.26 & $0.035^{* *}$ & -0.50 & -0.01 \\
\hline 5. & 16 & $4.21 \pm 0.55$ & $4.54 \pm 0.48$ & -0.33 & $0.016^{* *}$ & -0.60 & -0.06 \\
\hline 6. & 24 & $3.85 \pm 0.47$ & $4.17 \pm 0.47$ & -0.32 & $0.011^{* *}$ & -0.56 & -0.07 \\
\hline 7. & 32 & $3.77 \pm 0.44$ & $3.99 \pm 0.38$ & -0.22 & $0.045^{* *}$ & -0.43 & -0.01 \\
\hline 8. & 40 & $3.38 \pm 0.56$ & $3.71 \pm 0.63$ & -0.33 & $0.037^{* *}$ & -0.63 & -0.02 \\
\hline 9. & 48 & $3.30 \pm 0.52$ & $3.58 \pm 0.49$ & -0.27 & $0.041^{* *}$ & -0.54 & -0.01 \\
\hline 10. & 56 & $3.40 \pm 0.51$ & $3.57 \pm 0.52$ & -0.17 & $0.196^{*}$ & -0.44 & 0.09 \\
\hline 11. & 64 & $3.54 \pm 0.58$ & $3.76 \pm 0.42$ & -0.22 & $0.090^{*}$ & -0.48 & 0.03 \\
\hline 12. & 72 & $2.95 \pm 0.64$ & $3.29 \pm 0.61$ & -0.34 & $0.039^{* *}$ & -0.66 & -0.01 \\
\hline 13. & 80 & $2.93 \pm 0.59$ & $3.23 \pm 0.56$ & -0.30 & $0.048^{* *}$ & -0.60 & -0.01 \\
\hline 14. & 88 & $3.17 \pm 0.70$ & $3.28 \pm 0.47$ & -0.11 & $0.482^{*}$ & -0.42 & 0.20 \\
\hline 15. & 96 & $2.88 \pm 0.57$ & $3.22 \pm 0.36$ & -0.34 & $0.009^{* *}$ & -0.59 & -0.08 \\
\hline 16. & 104 & $2.77 \pm 0.75$ & $3.13 \pm 0.55$ & -0.35 & $0.042^{* *}$ & -0.69 & -0.01 \\
\hline 17. & 112 & $2.79 \pm 0.47$ & $3.12 \pm 0.33$ & -0.33 & $0.002^{* *}$ & -0.54 & -0.12 \\
\hline 18. & 120 & $2.48 \pm 0.59$ & $2.88 \pm 0.59$ & -0.40 & $0.012^{* *}$ & -0.70 & -0.09 \\
\hline${ }^{*}$ Not significant; ${ }^{* *}$ Significant (P<0.05); LL-Lower limit; UL-Upper limit & & & \\
\hline
\end{tabular}

\section{Pain assessment by visual analogue scale (VAS)}

Mean pain intensity difference (PID)

At baseline, mean pain intensity score in the tramadol group was $6.90 \pm 0.49 \mathrm{~cm}$ while in diclofenac group, it was
$6.70 \pm 0.53 \mathrm{~cm}$. After drug administration, the VAS scores in each of the group is presented in Table 6 .

The mean pain intensity difference assessed on $10 \mathrm{~cm}$ VAS was significantly greater $(\mathrm{P}<0.05)$ for tramadol group compared to the diclofenac group at all the time points except $88 \mathrm{hr}$ (Figure 3). 
Sum of pain intensity difference (SPID)

In the tramadol group, the sum of pain intensity difference over first 8 hours after the study drug administration was significantly greater than in the diclofenac group. Similarly, sum of pain intensity difference over 24, 48, 72, 96 and 120 hours in the tramadol group was also significantly greater $(\mathrm{P}<0.05)$ in the diclofenac group (Figure 4).

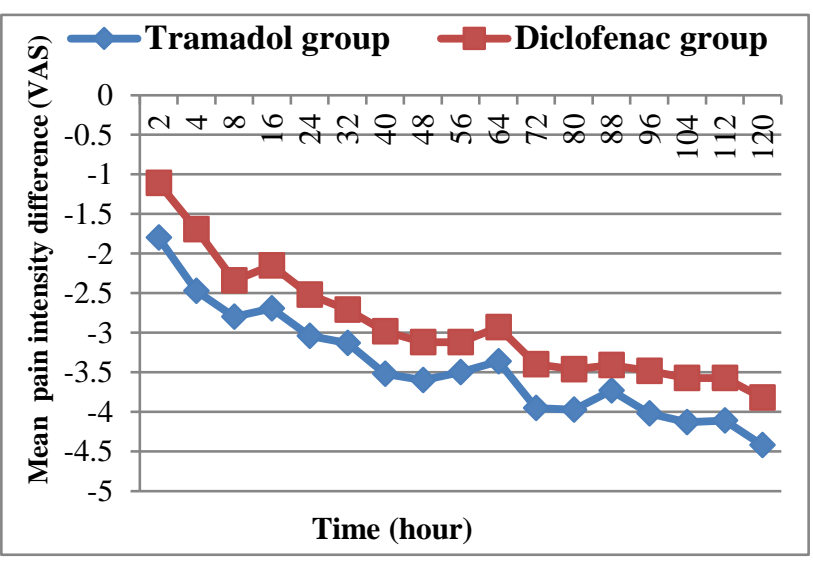

Figure 3: Mean pain intensity difference at each time points for 120 hours.

Maximum fall in pain intensity in each group

Over the $120 \mathrm{hr}$ period (5 days), both the group reported maximum fall in pain intensity scores. Tramadol group reported a maximum fall of $4.42 \pm 0.70 \mathrm{~cm}$ in pain intensity score against a fall of $3.82 \pm 0.68 \mathrm{~cm}$ in the diclofenac group, the difference being statistically significant $(\mathrm{P}<0.05)$.

\section{Pain assessment by quality of sleep}

The quality of sleep was assessed daily. For statistical analysis of the results in all patients, we compared the baseline (day 1) with days 2, 3, 4 and 5. Both the groups showed improvement in the quality of sleep. However, it was more significant in tramadol group compared to diclofenac group (Table 7).

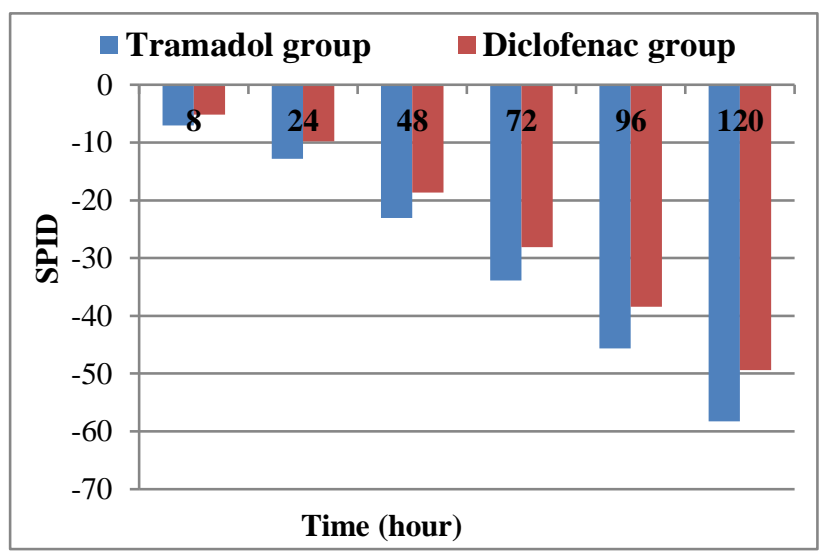

Figure 4: Sum of pain intensity difference (SPID) over different time points.

Table 7: Comparison of mean sleep score in tramadol and diclofenac groups.

\begin{tabular}{|llllllll|}
\hline SN & Day & $\begin{array}{l}\text { Mean sleep score } \\
\text { Tramadol group } \\
(\mathbf{n = 3 0})\end{array}$ & $\begin{array}{l}\text { Diclofenac } \\
\text { group }(\mathbf{n = 3 0})\end{array}$ & $\begin{array}{l}\text { Mean } \\
\text { difference }\end{array}$ & P value & \multicolumn{3}{c|}{$\begin{array}{l}\text { 95\% Confidence } \\
\text { interval }\end{array}$} \\
\hline 1. & 1 (Baseline) & $0.80 \pm 0.66$ & $0.73 \pm 0.63$ & 0.06 & $0.694^{*}$ & -0.27 & UL \\
\hline 2. & 2 & $1.53 \pm 0.50$ & $1.26 \pm 0.44$ & 0.26 & $0.035^{* *}$ & 0.01 & 0.51 \\
\hline 3. & 3 & $2.16 \pm 0.37$ & $1.80 \pm 0.61$ & 0.36 & $0.007^{* *}$ & 0.10 & 0.62 \\
\hline 4. & 4 & $2.46 \pm 0.62$ & $2.16 \pm 0.46$ & 0.30 & $0.039^{* *}$ & 0.01 & 0.58 \\
\hline 5. & 5 & $3.00 \pm 0.52$ & $2.46 \pm 0.57$ & 0.53 & $<0.001^{* *}$ & 0.24 & 0.81 \\
\hline${ }^{*}$ Not significant; ${ }^{* *}$ Significant $(\mathrm{P}<0.05) ;$ LL-Lower limit; UL-Upper limit & & & \\
\hline
\end{tabular}

Rescue analgesia

Rescue analgesia was not needed for any patients under our study.

Adverse drug effects (ADE)

Two patients in tramadol group and three patients in diclofenac group reported minor adverse effects but serious adverse effects were not noted in this study (Table $8)$.
Table 8: Adverse effects noted in tramadol and diclofenac groups.

\begin{tabular}{|c|c|c|c|}
\hline \multirow{2}{*}{ ADE } & \multicolumn{2}{|c|}{$\begin{array}{l}\text { Number of patients } \\
\text { presenting ADE }\end{array}$} & \multirow[t]{2}{*}{ Total } \\
\hline & $\begin{array}{l}\text { Tramadol } \\
\text { group }(n=30)\end{array}$ & $\begin{array}{l}\text { Diclofenac } \\
\text { group }(n=30)\end{array}$ & \\
\hline Nausea & 1 & 1 & 2 \\
\hline Headache & 1 & 0 & 1 \\
\hline Gastritis & 0 & 2 & 2 \\
\hline
\end{tabular}




\section{DISCUSSION}

In this study, patients were equally distributed $(\mathrm{P}>0.05)$ between the two treatment groups with respect to demographic features and baseline characteristics.

All the admitted patients under our study were traumatic patients who had suffered from fracture of their bones. The most common presentation was limb fracture (femur fracture in tramadol group and radius fracture in diclofenac group), similar to the observation of Pagliara et al, who noticed that fracture of upper and lower limbs was the most common finding while studying the safety and efficacy of tramadol compared with diclofenac in traumatic musculoskeletal pain. ${ }^{9}$

\section{Analgesic efficacy}

Though the need for a placebo in trials of analgesic efficacy has been emphasized, in this study a placebo was not used because both medications are well established analgesics, and thus it was considered unethical to administer a placebo to patients known to require effective analgesia. $^{20,21}$

Many patients cannot tolerate oral medication or may experience compromised gastrointestinal absorptive function after surgery; hence there is a need for the parenteral formulations of study medication. ${ }^{3}$ Therefore, injectable forms of the tramadol and diclofenac were used in this study for the initial 24hours followed by oral form of the drugs.

Numerous studies have compared tramadol with diclofenac in post-operative pain treatment in various types of surgical procedures. ${ }^{12-15}$ However, regarding their analgesic efficacy, there is no uniform agreement and their efficacy varies from study to study.

Courtney et al, conducted a single-blind (surgeon and research team member), prospective, randomized, controlled clinical trial in 64 patients, 11 years and older undergoing bipolar electro- cautery tonsillectomy. ${ }^{15}$ The patients received either oral tramadol or the oral diclofenac in the post-operative period. Pain scores for the 14 days were not significantly different between the oral tramadol and oral diclofenac groups.

Alwan et al, compared the effectiveness of paracetamol, diclofenac-sodium, and tramadol in controlling post tonsillectomy pain in 60 patients in their immediate postoperative period. ${ }^{12}$ Tramadol and diclofenac sodium were found quite effective in controlling post tonsillectomy pain but there was no significant difference in analgesic efficacy between tramadol and diclofenac groups.

Joshi et al, compared analgesic efficacy of tramadol and diclofenac-sodium used as a rectal suppository in a prospective, randomized, single blind and hospital based study in 60 patients of ASA grade 2 posted for cesarean section. ${ }^{14}$ Rectal suppository of diclofenac was found better alternative for postoperative analgesia in cesarean section as compared to tramadol.

In a double blind, randomized trial, the efficacy of tramadol hydrochloride with diclofenac sodium was compared in sixty patients who had undergone third molar surgery. ${ }^{13}$ The analgesic efficacy of the two drugs was equal except on day one when tramadol did better than diclofenac.

In a study of Cander et al, the effectiveness of diclofenac sodium, tramadol and metamizole sodium was compared in 100 patients who presented to the emergency room with traumatic injuries or fractures of the extremities. ${ }^{22}$ Tramadol was found to be the most effective analgesic among others.

A trial also showed an excellent results in the use of intramuscular tramadol for pain due to orthopedic and traumatologic surgery. ${ }^{2}$ Similar to the trial, the painrelieving action of tramadol in our study was quicker, as seen after the first dose and confirmed by patient assessments of pain after the operation. It has been reported that intramuscular tramadol 100mg, given postoperatively, has an analgesic effect equivalent to $30 \mathrm{mg}$ of pentazocine and is less potent than $10 \mathrm{mg}$ of morphine. $^{23,24}$

In the present study, the differences in pain intensity from both treatment groups began to emerge from 2 hours after the first dose administration. Mean pain intensity difference assessed on $10 \mathrm{~cm}$ VAS was significantly greater in the tramadol group compared to diclofenac group at all the time points except $88 \mathrm{hr}$ till the study period (i.e, upto $120 \mathrm{hr}$ ).

Sum of pain intensity difference (SPID) is an outcome measure that summarizes treatment response over a clinically relevant period. ${ }^{25}$ In the present study, SPID was compared over 8, 24, 48, 72, 96 and over 120 hours. In the tramadol group, SPID observed at these time points was significantly greater than that was in the diclofenac group.

Moreover, in this study, tramadol also demonstrated superiority over diclofenac in terms of secondary efficacy variables like maximum fall in pain intensity score. Tramadol group reported a maximum fall of $4.42 \pm 0.70 \mathrm{~cm}$ in pain intensity score against a fall of $3.82 \pm 0.68 \mathrm{~cm}$ in the diclofenac group. Thus, though both of the drugs produced good analgesic effect in the patients, the analgesic efficacy of tramadol was found significantly superior to that of diclofenac. Our findings were in accordance with the observation of pagliara et al. ${ }^{9}$

\section{Quality of sleep}

Since lack of sleep can exacerbate pain, improvement of sleep is an important goal of pain management. ${ }^{26}$ In the current study, both of the drugs showed an improvement 
in quality of sleep in the study period, similar to the report of Pagliara et al, who assessed the quality of sleep in 120 patients randomized to receive either tramadol or diclofenac for relief of traumatic musculoskeletal pain and found that both the drugs showed improvements in quality of sleep. ${ }^{9}$ However, in contrast to their report where there was no statistical significance between the groups, we noticed that tramadol has shown significantly better quality of sleep every night than diclofenac.

\section{Adverse effects}

No serious adverse effects were observed in either of the treatment groups in this study. Only few minor side effects noted in our study may be due to an assessment of adverse effects over short period of our study time.

The major limitations of our study were the following:

- The study was an open label study. Double blind comparisons would give more valid result.

- The study had small number of research cases. Involvement of large number of cases would strengthen the statistical validity.

\section{CONCLUSION}

The results of this study indicate that tramadol thrice a day provides an effective and well tolerated relief from postoperative pain with better quality of sleep than diclofenac-sodium thrice a day. Hence tramadol can be considered as an effective alternative to traditional NSAIDs in the treatment of postoperative pain in orthopedic patients.

\section{ACKNOWLEDGEMENTS}

Authors would like to thank to all the patients who participated in this study. The authors are also thankful to all faculty members, residents and staff of Department of Pharmacology and Orthopedics, College of Medical Sciences-Teaching Hospital, Bharatpur, Nepal for their kind help and co-operation to conduct the study.

\section{Funding: No funding sources}

Conflict of interest: None declared

Ethical approval: The study was approved by the Institutional Review Committee of CMS-TH

\section{REFERENCES}

1. Williams M, Kowaluk EA, Arneric SP. Emerging molecular approaches to pain therapy. J Med Chem. 1999;42:1481-500.

2. Lanzetta A, Vizzardi M, Letizia G, Martorana U, Sanfillipo A, Osti L. Intramuscular tramadol versus ketorolac in patients with orthopedic and traumatologic post-operative pain: a comparative multicenter trial. Curr Ther Res. 1998;59(1):39-47.
3. Pareek A, Chandurkar N, Gupta A, Desai Y, Kumar SH, Swamy A, et al. Comparative evaluation of efficacy and safety of etodolac and diclofenac sodium injection in patients with post-operative orthopedic pain. Curr Med Res Opin. 2011;27(11):2107-15.

4. Khosraftar E, Anvari HM, Assadi HK, Abdulamir AS, Abubakar F. Comparative study on the effectiveness of acetaminophen and diclofenac pretreatment in the relief of acute pain after outpatient surgery. Eur J Dent Med. 2011;3(1):23-7.

5. Hynes D, McCarroll M, Provost OH. Analgesic efficacy of parenteral paracetamol and diclofenac in post-operative orthopaedic pain. Acta Anaesthesiol Scand. 2006;50:374-81.

6. Fields M, Murray S. The effectiveness of Tramadol in acute pain management. Accident Compensation corporation. Available at: http://www.2ndchance.info/marijuanaMurray2005.pdf (accessed 1 December 2013).

7. Beck A, Krishchak G, Sorg T, Augat P, Farker K, Merkel U, et al. Influence of diclofenac (group of nonsteroidal anti-inflammatory drugs) on fracture healing. Arch Orthop Trauma Surg. 2003;123:327-32.

8. Ofman JJ, MacLean CH, Straus WL, Morton SC, Berger ML, Roth EA, Shekelle P. A metaanalysis of severe upper gastrointestinal complications of nonsteroidal antiinflammatory drugs. The Journal of rheumatology. 2002 Apr 1;29(4):804-12.

9. Pagliara L, Tornago S, Metastasio J, Peretti G, Albisetti W, Thovez G. Tramadol compared with diclofenac in traumatic musculoskeletal pain. Curr Ther Res. 1997;58(8):473-80.

10. Raffa RB, Friderichs E, Reimann W, Shank RP, Codd EE, Vaught JL. Opioid and non-opioid component independently contribute to the mechanism of action of tramadol, an atypical opioid analgesic. J Pharmacol Exp Ther. 1992;260:275-85.

11. Tripathi KD. Opioid Analgesics and antagonists. In: Tripathi KD, editor. Essentials of Medical Pharmacology. $6^{\text {th }}$ Ed. New Delhi: Jaypee Brothers; 2008:453-468.

12. Alwan AM, Aljibori AS, Shinawa RM. Comparision of post tonsillectomy analgesic drugs (paracetamol, diclofenac sodium, and tramadol). Tikrit J Pharm Sci. 2009;5(2):156-9.

13. Shah I, Zaeem K, Ibrahim MW, Hussain I, Hassan A. Comparision of analgesic efficacy of tramadol hydrochloride with diclofenac sodium in dentoalveolar surgery. Pak Oral Dent J. 2008;28(2):241-4.

14. Joshi VS, Vyavahare RD, Khade G, Shiledar V, Jamadar NP. Comparative study of analgesic efficacy of rectal suppository of tramadol versus diclofenac in suppressing post-operative pain after cesarean section. Int J Health care Biomed Res. 2013;1(2):32-7.

15. Courtney MJ, Cabraal D. Tramadol Vs diclofenac for post tonsillectomy analgesia. Arch Otolaryngol Head Neck Surg. 2001;127:385-8.

16. Melzack R. The McGill pain questionnaire: Major properties and scoring methods. Pain. 1975;1(3):27799. 
17. Gould D. Information point: visual analogue scale (VAS). J Clin Nurs. 2001;10:697-706.

18. Daniels S, Melson T, Douglas A, Hamilton DA, Lang E, Carr DB. Analgesic efficacy and safety of a novel injectable formulation of diclofenac compared with intravenous ketorolac and placebo after orthopedic surgery: a multicenter, randomized, double-blinded, multiple-dose trial. Clin J Pain. 2013;29(8):655-63.

19. Beaulieu AD, Peloso PM, Haraoui B, Bensen W, Thomson G, Wade J, et al. Once-daily, controlledrelease tramadol and sustained-release diclofenac relieve chronic pain due to osteoarthritis: a randomized controlled trial. Pain Res Manage. 2008;13(2):103-10.

20. Mizraji M. Clinical response to etodolac in the management of pain. Eur $\mathbf{J}$ Rheumatol Inflamm. 1990;10(1):35-43.

21. Comfort MB, Tse AS, Tsang AC, McGrath C. A study of the comparative efficacy of three common analgesics in the control of pain after third molar surgery under local anaesthesia. Aust Dent J. 2002;47:327-30.

22. Cander B, Girisgin S, Koylu R, Gul M, Kocak S. The effectiveness of analgesics in traumatic injuries of the extremities. Adv Ther. 2005;22(5):462-6.
23. Kupers R, Callebaut V, Debois V, Camu F, Verborgh C, Coppejans H, et al. Efficacy and safety of oral tramadol and pentazocine for postoperative pain following prolapsed intervertebral disc repair. Acta Anaesthesiologica Belgica. 1994 Dec;46(1):31-7.

24. Lehmann KA. Tramadol for the management of acute pain. Drugs. 1994;47(1):19-32.

25. Tfelt-Hansen P, McCarroll K, Lines C. Sum of Pain Intensity Differences (SPID) in migraine trials. A comment based on four rizatriptan trials. Cephalalgia. 2002;22:664-6.

26. Richter W, Barth H, Flohe L, Giertz H. Clinical investigation on the development of dependence during oral therapy with tramadol. Arzneimittelforschung. 1985;35:1742-4.

Cite this article as: Paudel R, Deka A, Gupta HK, Nepal HP. Comparative evaluation of analgesic efficacy of tramadol and diclofenac-sodium in postoperative orthopedic patients. Int J Basic Clin Pharmacol 2017;6:2676-83. 